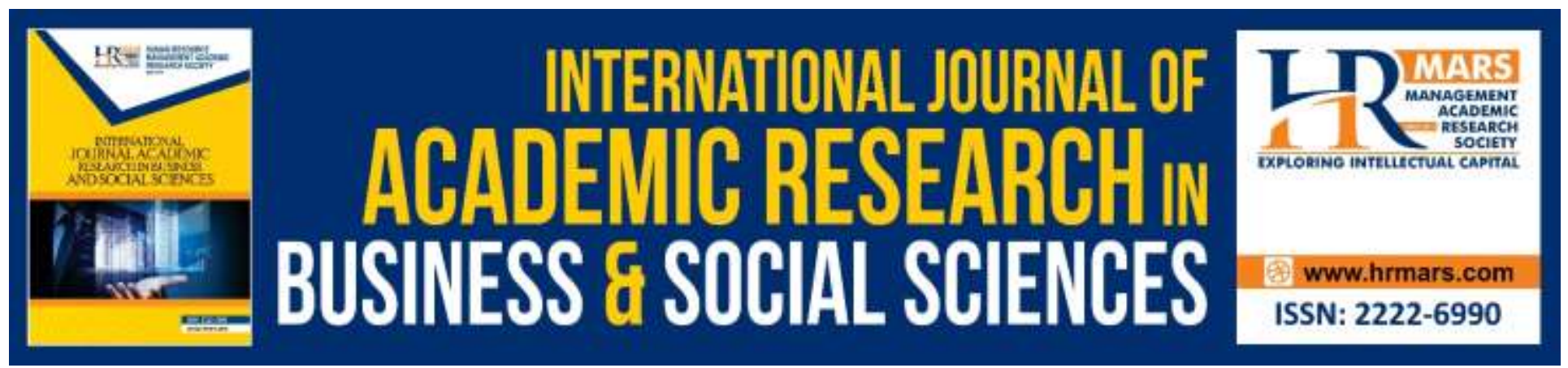

\title{
The Perceived Influence of English Language on Islamic Identity and Value of Students Enrolled in an Islamic-Oriented Human Resource Education Programme
}

Ahmad Irfan Jailani, Nurhazwani binti Abdul Halim, Suthagar Narasuman

To Link this Article: http://dx.doi.org/10.6007/IJARBSS/v10-i6/7329

DOI:10.6007/IJARBSS/v10-i6/7329

Received: 22 April 2020, Revised: 28 May 2020, Accepted: 26 June 2020

Published Online: 30 June 2020

In-Text Citation: (Jailani et al., 2020)

To Cite this Article: Jailani, A. I., Halim, N. binti A., \& Narasuman, S. (2020). The Perceived Influence of English Language on Islamic Identity and Value of Students Enrolled in an Islamic-Oriented Human Resource Education Programme. International Journal of Academic Research in Business and Social Sciences, 10(6), 506-521.

Copyright: (C) 2020 The Author(s)

Published by Human Resource Management Academic Research Society (www.hrmars.com)

This article is published under the Creative Commons Attribution (CC BY 4.0) license. Anyone may reproduce, distribute, translate and create derivative works of this article (for both commercial and non-commercial purposes), subject to full attribution to the original publication and authors. The full terms of this license may be seen

at: http://creativecommons.org/licences/by/4.0/legalcode

Vol. 10, No. 6, 2020, Pg. 506 - 521

Full Terms \& Conditions of access and use can be found at http://hrmars.com/index.php/pages/detail/publication-ethics 


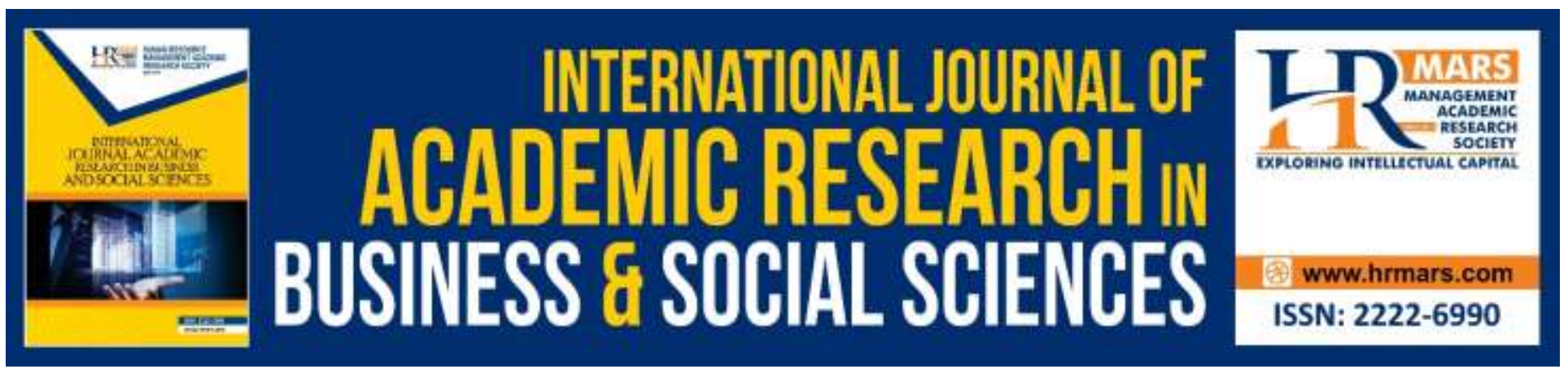

\title{
The Perceived Influence of English Language on Islamic Identity and Value of Students Enrolled in an Islamic-Oriented Human Resource Education Programme
}

\author{
Ahmad Irfan Jailani ${ }^{1}$, Nurhazwani binti Abdul Halim², Suthagar \\ Narasuman ${ }^{3}$ \\ ${ }^{1}$ Faculty of Language and Education, KUIM, Melaka, Malaysia., ${ }^{2}$ Academy of Language Studies, \\ Universiti Teknologi Mara, Pahang, Malaysia, ${ }^{3}$ Faculty of Education UiTM Selangor, Puncak Alam \\ Campus \\ Email: ahmadirfanj@kuim.edu.my, hazwanihalim112@uitm.edu.my, suthagar@uitm.edu.my
}

\begin{abstract}
In Malaysia, English has been heavily emphasized in education with the main goal of proficiency in both Malay and English for all. Like any other language, English is associated with the culture of its native speakers. Hence, it may also be perceived as the carrier of Judeo-Christian values and Western cultures. This may lead to the perception that learning English is a threat to Islamic identity and values, causing rejection. Therefore, with the increasing demand for capable English speakers in the Malaysian workplace, it is imperative to identify whether students enrolled in tertiary programmes perceive the language as influential towards their identity and values as Muslims. Hence, students enrolled in an Islamic University College under the Human Resource programme tailored to inculcate Islamic values are identified as respondents for the study. The study employed a quantitative design utilising a questionnaire developed from an analysis of past literature. Descriptive statistics and ANOVA test through SPSS were utilized to answer the research questions. Overall a mean score of $1.38(\mathrm{SD}=.58)$ was an indication that the respondents have high acceptance towards the English language. The respondents also strongly disagreed that English negatively influenced their religious identity and Islamic values. It is hoped that the findings from the study provides valuable and significant insights to English language teaching.
\end{abstract}

\section{Introduction}

English is one of the most widely used language around the world. In many non-native speaking countries, English is spoken as a second language or used as a foreign language. Over the years, the mastery of English has become a major requirement for advancement in both education and the working sector. In Malaysia, English is taught as second language with the main goal of 
INTERNATIONAL JOURNAL OF ACADEMIC RESEARCH IN BUSINESS AND SOCIAL SCIENCES

Vol. 10, No. 6, June, 2020, E-ISSN: 2222-6990 @ 2020 HRMARS

attaining proficiency in both Malay and English for all Malaysians (Malaysian Education Blueprint). Therefore, the learning of English is definitely compulsory for every student in Malaysia.

\section{Background of the Study}

English, like any other language, is associated with the culture, beliefs, religion and actions of its native speakers. Being the most commonly spoken language by native and non-native speakers across the world, English brings with it a set of perceived social sentiments than goes beyond the function of communication and its role as a lingua franca. According to (Mohd-Asraf, 2005), other than giving people the advantage for educational and social advancement, English is also perceived as the carrier of Judeo-Christian values and Western cultures. This factor implicates various images, both positive and negative to the Muslims. The fact that English is associated with Christianity and Western values may influence the way the language is viewed by society in Malaysia, which comprises mostly of Muslims.

These views and sentiments about English have only heighten after the one event that changed the atmosphere around the world, the 9/11. In the aftermath of the tragedy, most of the things written in English about Islam and Muslims have not exactly been positive. Specifically, Alazzany (2008) as discussed by Jahedi, Abdullah, \& Mukundan (2014) discovered that news discourse on Islam and Muslims after the event was dominated by Ideological themes of violence, evil, and threat. Understandably, this led to misconceptions about the nature of the language as well as its influence on Muslims in general.

The bias against Islam and Muslim was found to be common in English media. A review of past studies on the portrayal of Islam, Muslims and Iran by Jahedi et al., (2014) found that in the case of Israel and Palestine, the Muslim majority Palestinians were referred to as backwards whereas the non-Muslim Israelites backed by English-speaking Americans were peace-loving and virtuous. "Sternwilled" and "autocratic" were replaced with "religious zealots" in describing Iran before and after the Iranian revolution. This led to negative perceptions among Muslims towards English, the language of the people who have a lot of negative perceptions on them. This might directly or indirectly influence the learning of English in Malaysia, especially among the majority Muslim population.

The disdain is actually mutual; perhaps best exemplified by the Egyptian revolution in 2011. The president of Egypt at the time, Hosni Mubarak was accused of being a pro-western dictator and was later replaced by political Islamist parties (Abouelhassan \& Meyer, 2016).

\section{Problem Statement}

There are various different views about the learning of English as a second language in Malaysia. Ozog (1989) as cited by Mohd-Asraf (2005) mentioned that when interviewed about what English means and its rightful place in Malaysia, all 50 students interviewed from International Islamic University Malaysia (UIA) believed that English was the medium through which Western cultures penetrates the country. This perception comes as no surprise as second language teacher education mostly emphasizes on the necessity of including social, cultural, political, and institutional aspects of the language itself (Hadi, 2016). To an extreme, some Malay Muslims also believe that learning English meant learning the language of the Christians or the language of the colonialists and by learning this language they would become more like the whites (Asmah, 1992). 
Acquiring a language is always related to identity. When learning a new language, a person might eventually develop a new identity that will be apparent when using the language. This is definitely the case in a study conducted among Turkish students who reported development and awareness of multiple identities while learning English (Atay \& Ece, 2009). However, they still acknowledged their Turkish and Muslim identities over the Western identity developed within them.

In another study, a participant responded that the use of English language is associated with not being a Muslim (Kim, 2003). Some languages are very much related to religion as how Arabic is related to Islam, Hebrew is related to Judaism and English is related to Christianity. This could lead to the perception that learning English is as a threat to Islamic identity. Rahman (2009) mentioned about this in his research where he stated that in India and Pakistan, English was seen as a threat to faith and their way of life especially to Muslims who are undereducated.

Despite these concerns, Islam has never been opposed to learning a new language generally and education specifically. Abouelhassan \& Meyer (2016) stated in their study that the pessimistic argument that Islam is at odds with modernization and thus will be biased towards the learning of the English language is completely false. Furthermore, they eloquently elaborated on how western style schooling was incorporated into the Egyptian, Iranian and Turkish classrooms in the $19^{\text {th }}$ century in order to improve Muslim economies through trade and other commercial endeavours. A study in Iran also found that despite the emphasis on the national language, Persian, teachers at the tertiary level of education valued English as a medium of instruction. This is due to concerns over the inadequacies of available resources in their mother tongue. (Zare-ee \& Hejazi, 2017)

Looking at these different findings on how language can affect a person's identity and the different ways of viewing the learning of English language towards Muslims, it would be pertinent to see how students enrolled in an Islamic-oriented Human Resource (HR) education programme would perceive the learning of English today. Specifically, there were several objectives that the study wanted to accomplish which are:

1. Identify the level of acceptance of English language by students enrolled in Islamic-oriented HR education programme

2. Identify the perceived influence of English on Islamic identity and value among students enrolled in Islamic-oriented HR education programmes

3. Determine whether there is any significant difference between the students' acceptance of English and their perception on the influence the language has on their Islamic identity and value

With these in mind the study set out to answer the following questions:

1. What is the level of acceptance of English by students enrolled in Islamic-oriented HR education programme?

2. How do students enrolled in Islamic-oriented education programmes perceive the influence of English on their Islamic identity and value?

3. Is there any significant difference between the students' acceptance of English and their perception on the influence the language has on their Islamic identity and value?

\section{Literature Review}

Language and its influence on a person's identity, and way of thinking is an issue that has been widely discussed in past studies; particularly when it involves a community that differs in their way of life and culture. The issue of culture is related to values and values are usually related to faith and 
religion. Ahmad \& Rabai (2014) stated in his research that the first influence of language was first proposed by Sapir and Whorf in which they believed that the way our thoughts function and the way we see the world is determined by our language. Thus, this makes the learning of any language, a very crucial decision especially when it is being implemented throughout the whole country.

Ozog (1989) as cited by Mohd-Asraf (2005) stated that there was a time when the Malays were going through a phase of rejection towards Western ideas and practices. The rural Malays did not see the significance of English and believed that it was a non-Islamic language. This was hugely due to the fact that the English-speaking British Empire had once colonized Malaysia leaving a very negative impression upon its culture and values with no exception to its language. The idea that English was used during those years to spread Christianity left a more negative view of the language. The locals, especially the Muslim Malays at that time felt sceptical of the language due to its direct relation to Christianity.

Pennycook (1994) stated that when Muslims used English, there were those who would feel that there was a conflict between their cultural values and worldview. In this case, the conflict was conveyed through English and their Islamic values. English, being associated with another very influential religion definitely influenced how it was viewed by the community of a different religion. Faith and religion are very sensitive issues and thus anything that could indicate a manipulation or interference to their faith would be considered taboo. Therefore, it was not a surprise when certain Muslims felt that learning English would create some sort of conflict within them.

In terms of education, English language mastery has received very strong attention. Most countries are teaching their students to master the English language as best as they could because of its global value. English language proficiency is often an indication of education, employment and social status. However, the teaching of English through the national education system have raised some negative sentiments. and concerns

Acquisition of a language means understanding the culture in which the language originates; hence non-natives will learn Western cultures and values while acquiring English. This is unavoidable since the learning of a language comes with its culture as a package. To teach a language apart from its culture would be impractical as authenticity plays a major part in the language learning process and thus, it would definitely involve cultural influence permeating from the materials used (Ahmad \& Rabai, 2014)

The concern over the transmission of western values from learning English has even led to suggestions on how to minimize its impact at religious schools in Indonesia. One of the propositions was to optimize Islamic messages in the instructional materials by using Islamic value-based authentic materials and textbooks (Umam, 2014).

Haggan (1998) as cited by Roscoe and Al-Mahrooqi (2012) also described the concerns of her students when they had to learn English literature because it required them to appreciate the nativespeakers' values and traditions which contradicted their own. In order to counter the problem, in Morocco, educationists had once argued that English should be taught separate from the culture of English-speaking countries and simply as an instrumental tool (Hyde, 1994). However, this theoretically would not work. This is because a language is best learned using authentic materials as it contains authentic languages and shows how it is used in some real-life situations (Brown \& Lee 2015). Therefore, teaching English outside of its cultural context would probably be very challenging and probably ineffective. 
In Malaysia, the belief that learning a new language would lead to an identity crisis was one of the prominent factors affecting the people's attitude towards the learning of English (Asmah, 1992). Most of them felt that the people who mastered the English language would eventually be like the Westerners and they refused to be seen as one. In a study on 14 adult Malaysian women to see how English affected the construction of their socio-cultural identities, one of the participants said that her Malay friends saw her use of English as "showing off" and that she was trying to be "like the whites" which could be related to the colonizer. Another participant stated that English is associated with not being a Muslim (Kim, 2003).

Nevertheless, despite some of the negative views on the learning of the English language among Muslims, not all of them share the same point of view. One of the participants in the previously mentioned study by Kim (2003) said that learning a new language does not have to mean internalizing its values. Adding to this, an earlier study found that majority of the students had a positive attitude towards English (Dan, Haroon, \& Naysmith, 1996). They also mentioned that Western culture does not necessarily equal negative culture and studying the language does not mean taking in its culture. It is vital for learners of the English language to have a positive attitude towards the language because it correlates significantly with achievement (Bidin, Jusoff, Aziz, Salleh, \& Tajudin, 2009).

These changes in the perception of English are important as the significance of mastering the English language is becoming clearer with advent of education and technology, especially social media. In some countries, English language proficiency is a requirement for job application (Ahmad \& Rabai, 2014), ("The Importance of the English Language", 2009).

With the increasing demand for the mastery of English at the workplace, it would be noteworthy to see whether there are any significant differences between acceptance of English and the perceived influence of the language on Islamic identity and value among Malaysian tertiary education students enrolled in an Islamic-oriented programme.

\section{Methodology}

A quantitative approach was chosen whereby questionnaires were utilized to measure the variables. Past studies were mostly qualitative; hence we believe a quantitative approach is warranted. SPSS was used to translate the raw data into meaningful information.

The population was identified as students enrolled in a Human Resource (HR) programme at a local university college. However, unlike other HR education programmes from other higher learning institutes, Islamic values and teachings are highly emphasized here. This is primarily because the higher learning institute where the respondents are enrolled identifies itself as an Islamic university college. In fact, the name of the programme is Diploma in Islamic Studies and Human Resource Management. Hence, all students are required to take compulsory subjects related to the teachings of Islam. One of the notable courses that the respondents have to take is Methodology in Preaching Islamic Values. Based on these characteristics, we believe the respondents suit the need of the study. 303 students were enrolled in the programme at the time of writing and out this, 169 respondents were selected using random selection technique.

The questionnaire for this study was designed from the ground up because previous studies mostly approached this particular area of research qualitatively. Interviews were the main choice of 
INTERNATIONAL JOURNAL OF ACADEMIC RESEARCH IN BUSINESS AND SOCIAL SCIENCES

Vol. 10, No. 6, June, 2020, E-ISSN: 2222-6990 @ 2020 HRMARS

instrument from past research. Hence, the findings from past research as well as the research questions and objectives of the study guided the creation of this questionnaire.

The items were clustered into 3 sections:

1) Acceptance of English language

This section had 8 items which were statements on English language acceptance. The respondents identified their agreement with each statement through a 5-point Likert scale. Since the statements were negatively constructed, 1 indicated strong disagreement and 5 indicated strong agreement. Constructions of the items in this section examined the perception of the respondents on the importance of English in their education and everyday life.

2) Perceived influence of English on religious identity

The second section of the questionnaire identified the respondents' perception on the influence of English on their religious identity. The decision to include a section specific to religious identity was done due to the findings and arguments from past study where students can develop multiple identities from language learning (please refer to the literature review of this article for the discussion). Similarly, each item represented a statement where the respondents indicated their agreement via a 5-point Likert scale. The statements were on the perceived impact that English brought through western culture and secularization.

3) Perceived influence of English on Islamic values

The third and final section determined the perceived influence of English on the respondents' Islamic values. The unavoidable inclusion of western values and culture through authentic materials in the teaching of English as well as exposure to the language outside the classroom through mass media prompted the creation of this section. To determine the perception on the influence of English to Islamic values, the same 5-point Likert scale was also used.

The statements in the questionnaire are all in English and Malay in order to avoid any misunderstanding; hence improving its face validity. To ensure there was no mistranslation, two English language educators were appointed to check for faults and inconsistencies. Their thoughts on the items' appropriateness for each section were also considered.

For reliability, a pilot-test was conducted on three classes of 57 students. The internal consistency of the questionnaire when administered was $\alpha=.92$ which meant that the level of overall reliability of the questionnaire on perceived influence of English language on religious identity and Islamic value was acceptable. Specifically, the items on English acceptance scored an alpha reliability value of $\alpha=.89$. Items on perceived influence of English on religious identity and values scored alpha values of .79 and .85 respectively.

In answering the research questions, the respondents were divided into 5 different groups according to their level of acceptance of the English language. This requires the identification of the mean average from the descriptive statistics analysis of the eight items on "acceptance of English language". Division of respondents according to their acceptance of English can be seen in Table 1. 
INTERNATIONAL JOURNAL OF ACADEMIC RESEARCH IN BUSINESS AND SOCIAL SCIENCES Vol. 10, No. 6, June, 2020, E-ISSN: 2222-6990 @ 2020 HRMARS

Table 1: Division of respondents according to their mean level of acceptance of English

\begin{tabular}{ll}
\hline Level of Acceptance & Range \\
\hline Strong Acceptance & $1.0-1.8$ \\
Acceptance & $1.8-2.6$ \\
Neutral & $2.6-3.4$ \\
Rejection & $3.4-4.2$ \\
Strong Rejection & $4.2-5.0$ \\
\hline
\end{tabular}

Then the respondents' perception on the influence of English on their Islamic identity and Islamic value was identified by two sections in the questionnaire that consisted of 5 (5-point scale) items respectively. The mean averages of all 5 items were identified to find the respondents' level of agreement. A high score indicates a high level of agreement. As mentioned before, since the statement for each item is negatively toned, a high score means that the perception was negative.

Next, a one-way ANOVA test was conducted to identify whether there was a statistically significant difference between the groups and their perception on the level of influence that English has on their religious identity and value. From the result of the test, if the P value was lower than .05, it indicated statistical significance between the two variables and warrants a post-test. Tukey HSD post-test allowed comparison of mean scores and the level of significance between each group.

\section{Findings and Discussion}

Table 3 shows the descriptive statistics of items on the respondents' acceptance of English language. Highest scoring item was I dislike it when my friends speak in English with $\mathrm{M}=1.63(\mathrm{SD}=.85)$. Next were the items "English language is not useful for everyday situation" (M=1.50, SD=.94) and "It is not important to learn English" ( $M=1.47, S D=.93)$. Fourth was "English language does not help me with my studies" with average score of $1.39(\mathrm{SD}=.83)$. "Learning English is a waste of time" was fifth with $\mathrm{M}=1.29$ ( $\mathrm{SD}=.74)$. Two items which were "Knowing English does not give me any advantage" $(S D=.59)$ and "Being able to communicate in English is not important" (SD=.61) scored similarly at 1.27. The lowest scoring item was "English language is not a useful language to learn $(M=1.25$, $\mathrm{SD}=.61)$. Overall, the mean score of $1.38(\mathrm{SD}=.58)$ was an indication that the respondents have high acceptance towards the English language.

Table 3: Descriptive statistics of items on the acceptance of English language

\begin{tabular}{lccc}
\hline & $\mathrm{N}$ & Mean & Std. Deviation \\
\hline It is not important to learn English & 169 & 1.47 & .93 \\
Learning English is a waste of time & 169 & 1.29 & .74 \\
English language does not help me with my studies & 169 & 1.39 & .83 \\
English language is not useful for everyday situation & 169 & 1.50 & .94 \\
I dislike it when my friends speak English & 169 & 1.63 & .85 \\
Knowing English does not give me any advantage & 169 & 1.27 & .59 \\
English language is not a useful language to learn & 169 & 1.25 & .61 \\
Being able to communicate in English is not important & 169 & 1.27 & .61 \\
\hline Overall & 169 & 1.38 & .58 \\
\hline
\end{tabular}


INTERNATIONAL JOURNAL OF ACADEMIC RESEARCH IN BUSINESS AND SOCIAL SCIENCES Vol. 10, No. 6, June, 2020, E-ISSN: 2222-6990 @ 2020 HRMARS

Table 4 shows the distribution of the 169 respondents based on their acceptance of the English language. Majority of the respondents had high acceptance towards the English language ( $n=135,79.9 \%) .23$ respondents also accepted the language although not as high. There were $8(4.7 \%)$ respondents who were neutral towards English and 3 (1.8\%) who rejected it.

Table 4: Distribution of respondents according to their level of acceptance of English language

\begin{tabular}{lcc}
\hline & Frequency & Percentage \\
\hline High Acceptance & 135 & 79.9 \\
Acceptance & 23 & 13.6 \\
Neutral & 8 & 4.7 \\
Rejection & 3 & 1.8 \\
\hline Total & 169 & 100.0
\end{tabular}

\section{Positive perception towards English by all the respondents}

Despite enrolment in an Islamic-oriented HR education programme, data analysis shows that the respondents have a strong positive acceptance of the English language, which contradicts the findings made by Mohd-Asraf (2005), who stated that there were substantial amount of literature that documented the attitudinal resistance of Muslim towards English., The reason for this could be because most of these studies took place in the Arab world where English is coined with disloyalty, westernization and colonization (Ahmad \& Rabai, 2014). By comparison, Malaysia promotes the importance and use of English by Malaysians. The language is even acknowledged as the second language of the country. When the language is accepted and widely used, it receives less resistance by the population. The same can be said in the Arab world in the past where English was the language of teaching and instruction in many local universities due to the alliance between Arab nations and the West (Ahmad \& Rabai, 2014). However, because of politics, ideologies, beliefs as well as interferences from the English-speaking United States of America in the affairs of Muslim-majority countries, the atmosphere has changed drastically. Therefore, the government and society of Malaysia plays an important role in ensuring that English is accepted by Malaysians.

Research Question 2: How do students enrolled in Islamic-oriented education programme perceive the influence of English on their religious identity and value?

Table 5: Descriptive statistics of items on the perceived influence of English on Islamic identity

\begin{tabular}{llcc}
\hline $\begin{array}{l}\text { Item } \\
\text { No. }\end{array}$ & \multicolumn{2}{c}{$\mathrm{N}$ MeanStd. Deviation } \\
\hline 1 & English is the language of the non-Muslims & 1691.69 & 1.06 \\
2 & English language brings westernization to my identity as a Muslim & 1691.61 & .85 \\
3 & English language brings secularization to my identity as a Muslim & 1691.59 & .77 \\
4 & Learning English is a threat to my Islamic identity & 1691.40 & .95 \\
5 & English language negatively influences my worldview as a Muslim & 1691.37 & .61 \\
\hline & Overall & 1691.53 & .61 \\
\hline
\end{tabular}

Table 5 shows the analysis of items on the perceived influence of English on Islamic identity. Out of the 5 items, "English is the language of the non-Muslims" scored the highest mean of 1.69 
INTERNATIONAL JOURNAL OF ACADEMIC RESEARCH IN BUSINESS AND SOCIAL SCIENCES Vol. 10, No. 6, June, 2020, E-ISSN: 2222-6990 @ 2020 HRMARS

$(S D=1.06)$ and followed closely by "English language only brings westernization to my identity as a Muslim" $(M=1.61, S D=.85)$. At third $(M=1.59, S D=.77)$ and fourth $(M=1.40, S D=.95)$ were items "English language only brings secularization to my identity as a Muslim" and "Learning English is a threat to my Islamic identity". The item with the lowest score was "English language negatively influences my worldview as a Muslim" with $1.37(\mathrm{SD}=.61)$. The overall mean score of $1.53(\mathrm{SD}=.61)$ determined that the respondents strongly disagree that English negatively influenced their Islamic identity.

Table 6: Descriptive statistics of items on perceived influence of English on Islamic values

\begin{tabular}{llrrr}
\hline No. & & $\mathrm{N}$ & Mean & $\begin{array}{c}\text { Std. } \\
\text { Deviation }\end{array}$ \\
\hline 1 & $\begin{array}{l}\text { English language imposes the values from the western world } \\
\text { on Muslims } \\
2\end{array}$ & 169 & 1.69 & .99 \\
$\begin{array}{l}\text { English language imposes the values from the western world } \\
\text { on Muslims }\end{array}$ & 169 & 1.39 & .86 \\
3 & $\begin{array}{l}\text { Learning English does not make me a better Muslim } \\
\text { English language negatively influences my religious values }\end{array}$ & 169 & 1.40 & .70 \\
5 & $\begin{array}{l}\text { English language is a source of secular views that affects my } \\
\text { religious values }\end{array}$ & 169 & 1.38 & .61 \\
\hline & Overall & 169 & 1.45 & .60 \\
\hline
\end{tabular}

Table 6 is a descriptive statistic on items related to the perceived influence of English on Islamic value. The highest mean score of $1.69(\mathrm{SD}=.99)$ was recorded by the item "English language imposes the values from the western world on Muslims". The second highest score $(\mathrm{M}=1.40, \mathrm{SD}=.70)$ was received by the item "Learning English does not make me a better Muslim". At number 3 was the item "English language imposes the values from the western world on Muslims" (M=1.39, $\mathrm{SD}=.86)$. Followed closely at number 4 is "English language negatively influences my religious values" $(\mathrm{M}=1.38, \mathrm{SD}=.61)$. The item "English language is a source of secular views that affects my religious values" received the lowest score of 1.37 ( $S D=.61)$. Overall, the items related to the perceived influence of English on Islamic values scored mean average of 1.45 (SD=.60). Therefore, overall, the respondents strongly disagree that English negatively influenced their Islamic values.

\section{Perceived influence of English on Islamic identity and values}

The recorded mean scores of $1.32(S D=.49)$ and $1.27(S D=.45)$ for perceived influence of English on Islamic identity and values respectively indicate that overall, the respondents perceived that the language had no effects at all to their identity and values as Muslims. On the contrary, MohdAsraf (2005) mentioned that English is seen as the embodiment and carrier of Judeo-Christian cultural values and westernization. It was even said that for British born Muslims who were not familiar with the Arabic language, their access to Islam was somehow "tainted" (Jaspal \& Coyle, 2010). This was because they only had access to the translated English version of the Koran instead of the Koran itself. Similarly, the community played an important role in this situation which influenced the beliefs of each individual. Arabic is viewed as the language of religion; whereas English is language of heritage. Although both were considered part of their identity, English was perceived to be unsuitable for religious use. The same can be said here in Malaysia where Arabic is the only language that can be 
INTERNATIONAL JOURNAL OF ACADEMIC RESEARCH IN BUSINESS AND SOCIAL SCIENCES

Vol. 10, No. 6, June, 2020, E-ISSN: 2222-6990 @ 2020 HRMARS

used for prayer and reciting the Koran. However, sermons and even doa' can still be done in Malay and English. Hence, Malaysian Muslims have a more tolerable view of language for religious use. This could be the reason why the respondents in this study did not believe that English language can influence their Islamic beliefs and identity.

Research Question 3: Is there any significant difference between the students' acceptance of English language and their perceived influence that the language has on their religious identity and values?

A one-way ANOVA between the respondents' level of acceptance of English (Table 4) and "the perceived influence of English on their Islamic Identity (Table 5) and values (Table 6) was conducted. This procedure helped to identify whether there was any statistical significance between the students' level of acceptance of English and their perception on its influence on their Islamic identity and values. The findings can be seen in the tables below.

Table 7: One-way ANOVA between level of acceptance of English and perceived influence of English on Islamic Identity

\begin{tabular}{|c|c|c|c|c|c|c|}
\hline & & $\begin{array}{l}\text { Sum of } \\
\text { Squares }\end{array}$ & $d f$ & $\begin{array}{l}\text { Mean } \\
\text { Square }\end{array}$ & $\mathrm{F}$ & Sig. \\
\hline \multirow[t]{3}{*}{$\begin{array}{l}\text { Religious } \\
\text { Identity }\end{array}$} & $\begin{array}{l}\text { Between } \\
\text { Groups }\end{array}$ & 10.01 & 3 & 3.34 & 10.45 & .00 \\
\hline & Within Groups & 52.71 & 165 & .32 & & \\
\hline & Total & 62.72 & 168 & & & \\
\hline
\end{tabular}

Table 8: One-way ANOVA between level of acceptance of English and perceived influence of English on Islamic Values

\begin{tabular}{llrrrrr}
\hline & \multicolumn{1}{c}{$\begin{array}{c}\text { Sum of } \\
\text { Squares }\end{array}$} & \multicolumn{1}{c}{ df } & Mean & Square & \multicolumn{1}{c}{ F } & Sig. \\
\hline Religious & Between & 14.98 & 3 & 4.99 & 17.66 & .00 \\
Value & Groups & 46.64 & 165 & .28 & & \\
& Within Groups & 61.62 & 168 & & & \\
& Total & & & &
\end{tabular}

From table 7 and 8, it can be observed that there was a statistically significant difference at the $p<.05$ level between the three levels of English language acceptance on the perceived influence of English on the respondents Islamic identity $[F(3,165)=10.45, p<.00]$ and Islamic values $[F(3,165)=17.66, p<.00]$. Therefore, the null hypotheses were rejected.

A post-hoc Tukey HSD test was conducted to identify the distribution of mean scores between each group and compare each level of acceptance with other levels. 
INTERNATIONAL JOURNAL OF ACADEMIC RESEARCH IN BUSINESS AND SOCIAL SCIENCES Vol. 10, No. 6, June, 2020, E-ISSN: 2222-6990 @ 2020 HRMARS

Table 9: One-way descriptive statistics between English language acceptance and its perceived influence on Islamic identity and values

\begin{tabular}{llccc}
\hline & & $\mathrm{N}$ & Mean & Std. Deviation \\
\hline Islamic & High Acceptance & 135 & 1.41 & .54 \\
Identity & Acceptance & 23 & 1.92 & .68 \\
& Neutral & 8 & 2.07 & .55 \\
& Rejection & 3 & 2.40 & .52 \\
& Total & 169 & 1.53 & .61 \\
Islamic & High Acceptance & 135 & 1.31 & .45 \\
Value & Acceptance & 23 & 1.80 & .89 \\
& Neutral & 8 & 2.35 & .37 \\
& Rejection & 3 & 2.47 & .50 \\
& Total & 169 & 1.45 & .60 \\
\hline
\end{tabular}

From the table above, it was seen that those with strong acceptance of English language score $1.41(\mathrm{SD}=.54)$ for Islamic identity and 1.31 (.45) for Islamic values. Whereas, respondents with normal amount of acceptance of English received mean score of 1.92 (SD=.68) for Islamic identity and 1.80 $(S D=.89)$ for Islamic values. The neutrals scored $2.07(S D=.55)$ and $2.35(S D=.37)$ for Islamic identity and Islamic values respectively. The 3 respondents who rejected the English language scored mean average of $2.40(\mathrm{SD}=.52)$ for Islamic identity and $2.47(\mathrm{SD}=.50)$ for Islamic value.

Table 10: Post-hoc Tukey HSD multiple comparison test between English language acceptance and the perceived influence on Islamic identity

\begin{tabular}{|c|c|c|c|c|c|c|c|}
\hline \multirow[b]{2}{*}{$\begin{array}{l}\text { Dependent } \\
\text { Variable }\end{array}$} & \multirow[b]{2}{*}{ (I) AccGrp5 } & \multirow[b]{2}{*}{ (J) AccGrp5 } & \multirow[b]{2}{*}{$\begin{array}{c}\text { Mean Difference } \\
(I-J)\end{array}$} & \multirow[b]{2}{*}{$\begin{array}{l}\text { Std. } \\
\text { Error }\end{array}$} & \multirow[b]{2}{*}{ Sig. } & \multicolumn{2}{|c|}{$\begin{array}{l}\text { 95\% Confidence } \\
\text { Interval }\end{array}$} \\
\hline & & & & & & $\begin{array}{l}\text { Lower } \\
\text { Bound }\end{array}$ & $\begin{array}{l}\text { Upper } \\
\text { Bound }\end{array}$ \\
\hline \multirow[t]{12}{*}{ Islamic Identity } & High & Acceptance & $-.51^{*}$ & .13 & .00 & -.84 & -.18 \\
\hline & Acceptance & Neutral & $-.66^{*}$ & .21 & .01 & -1.19 & -.13 \\
\hline & & Rejection & $-.99^{*}$ & .33 & .02 & -1.84 & -.13 \\
\hline & Acceptance & $\begin{array}{l}\text { High } \\
\text { Acceptance }\end{array}$ & $.51^{*}$ & .13 & .00 & .16 & .84 \\
\hline & & Neutral & -.15 & .23 & .91 & -.76 & .45 \\
\hline & & Rejection & -.48 & .35 & .52 & -1.38 & .42 \\
\hline & Neutral & $\begin{array}{l}\text { High } \\
\text { Acceptance }\end{array}$ & $.66^{*}$ & .21 & .01 & .13 & 1.19 \\
\hline & & Acceptance & .15 & .23 & .91 & -.45 & .76 \\
\hline & & Rejection & -.33 & .38 & .83 & -1.32 & .67 \\
\hline & Rejection & $\begin{array}{l}\text { High } \\
\text { Acceptance }\end{array}$ & $.99^{*}$ & .33 & .02 & .13 & 1.84 \\
\hline & & Acceptance & .48 & .35 & .52 & -.42 & 1.38 \\
\hline & & Neutral & .33 & .38 & .83 & -.67 & 1.32 \\
\hline
\end{tabular}

\footnotetext{
*. The mean difference is significant at the 0.05 level.
} 
INTERNATIONAL JOURNAL OF ACADEMIC RESEARCH IN BUSINESS AND SOCIAL SCIENCES Vol. 10, No. 6, June, 2020, E-ISSN: 2222-6990 @ 2020 HRMARS

The post-hoc Tukey test from table 10 indicates there were significant differences between the mean scores received by the strong acceptors of English and the all the other groups at the $p<.05$. However, there were no significant differences between the acceptors of English and the neutrals $(p=.91)$ and as well as those who rejected the language $(p=.52)$. The difference in mean score between the neutrals and respondents who rejected English was also insignificant $(p=.83)$. Hence, it was determined that respondents with high acceptance of English perceived English language to have less effects on their Islamic identity compared to the neutrals.

Table 11: Post-hoc Tukey HSD multiple comparison test between English language acceptance and the perceived influence on Islamic values

\begin{tabular}{|c|c|c|c|c|c|c|c|}
\hline $\begin{array}{l}\text { Dependent } \\
\text { Variable }\end{array}$ & (I) AccGrp5 & (J) AccGrp5 & $\begin{array}{c}\text { Mean } \\
\text { Difference (I- } \\
\mathrm{J})\end{array}$ & $\begin{array}{l}\text { Std. } \\
\text { Error }\end{array}$ & Sig. & $\begin{array}{c}95 \% \\
\text { Confidence } \\
\text { Interval }\end{array}$ & $\begin{array}{l}\text { Dependent } \\
\text { Variable }\end{array}$ \\
\hline \multirow[t]{12}{*}{ Islamic Value } & High & Acceptance & $-.49^{*}$ & .12 & .00 & -.80 & -.18 \\
\hline & & Neutral & $-1.03^{*}$ & .19 & .00 & -1.53 & -.53 \\
\hline & & Rejection & $-1.15^{*}$ & .31 & .00 & -1.95 & -.34 \\
\hline & Acceptance & $\begin{array}{l}\text { High } \\
\text { Acceptance }\end{array}$ & $.49^{*}$ & .12 & .00 & .18 & .80 \\
\hline & & Neutral & -.54 & .22 & .07 & -1.10 & .02 \\
\hline & & Rejection & -.66 & .33 & .19 & -1.50 & .18 \\
\hline & Neutral & $\begin{array}{l}\text { High } \\
\text { Acceptance }\end{array}$ & $1.03^{*}$ & .19 & .00 & .53 & 1.53 \\
\hline & & Acceptance & .54 & .22 & .07 & -.02 & 1.10 \\
\hline & & Rejection & -.12 & .36 & .99 & -1.05 & .81 \\
\hline & Rejection & $\begin{array}{l}\text { High } \\
\text { Acceptance }\end{array}$ & $1.15^{*}$ & .31 & .00 & .34 & 1.95 \\
\hline & & Acceptance & .66 & .33 & .19 & -.18 & 1.50 \\
\hline & & Neutral & .12 & .36 & .99 & -.81 & 1.05 \\
\hline
\end{tabular}

*. The mean difference is significant at the 0.05 level.

Another post-hoc Tukey HSD test (Table 11) was conducted between English language acceptance and the perceived influence of English language on Islamic values. Similar to the previous multiple comparisons test, there were significant differences recorded between respondents with high acceptance of English language with the average $(p<.00)$ and neutral $(p<.00)$ acceptance. Furthermore, the same result $(p<.00)$ was seen between respondents with high acceptance and those who reject the English language. On the other hand, there was no significant difference between the respondents who have average acceptance of English language with the neutrals $p=.07$ as well as those who rejected $(p=.19)$. The same was also uncovered between the neutrals and those who did not accept the language $(p=.99)$. Therefore, it can be concluded that those with high acceptance towards English see the language to have less effects towards their Islamic values when compared with the neutrals. 
INTERNATIONAL JOURNAL OF ACADEMIC RESEARCH IN BUSINESS AND SOCIAL SCIENCES Vol. 10, No. 6, June, 2020, E-ISSN: 2222-6990 @ 2020 HRMARS

\section{Significant difference among respondents' acceptance of English language and the perceived influence it has on Islamic identity and values}

The significant findings from the one-way ANOVA test and post-hoc Tukey HSD test provided the necessary insight into why the respondents in this study overall recorded a more positive view of English on religious identity and values compared to the past studies conducted in Arab countries. This result can simply be attributed to the fact that majority of the respondents have a higher acceptance of English. Because they are more exposed to the language through compulsory education and environment, they are more positive towards it. Hence, they do not see English as a threat to their Islamic identity and values.

Another probable reason as to why English is seen as a non-threat towards the Islamic identity and values of the majority of the respondents is because of the exposure towards the language that they received from outside the classroom. Findings from a study by Idris et al., (2019) found that an increase in exposure to the language leads to better achievement; thus this would make the language less intimidating. Furthermore, Malaysian students from tertiary education has been found to understand the needs and expectation of language classes (Ahmed, 2015). They realise that the language is imperative in their education and therefore, have no concern over any cultural values that it carries.

However, for a small number of respondents whose acceptance of English was statistically classified as being average, neutral, or just plain rejection, their perception on how English affects their Islamic identity and values was significantly different. Low level of acceptance towards English could help explain the findings from past studies conducted in the Arab world where the language was often viewed as a tool for westernization of values, culture and religious identity. In addition, Arabic respondents could have received less exposure towards the English language compared to the respondents in the present study.

\section{Significance of the Research}

The significance of this study is that overall; ESL teachers should take into consideration the students' religious background where the teaching and learning takes place. This is because students' views can influence their acceptance towards English which can promote or discourage language learning. Nevertheless, based on the findings of this study, it is arguable that the extreme perception that learning English will lead to identity crisis is a thing of the past among Malaysian Muslims. Hence, Malaysian teachers of English language should no longer be concerned that students may be disinterested in learning the language because of possible negative misconception towards it.

Findings from the study highlight the importance of positive acceptance towards English language because it significantly affects students' perception on its impact on their value and identity as Muslims. Therefore, teachers should find a way to promote students' acceptance of English. Students with higher level of acceptance perceived less influence from the language on their Islamic identity and value; hence there would be less resistance in acquiring the language. This should not be too difficult for ESL teachers in Malaysia as seen in this study whereby even students enrolled in an Islamic-oriented undergraduate programme mostly have favourable view of the language.

Conversely, the findings contradict the results of other studies which found students worrying about the cultural impact of learning English (Hyde, 1994) since it is difficult to learn a language without consideration of its native values (Ahmad \& Rabai, 2014). Perhaps, the positive perception among the respondents of this study when compared with past studies can be attributed to their 
INTERNATIONAL JOURNAL OF ACADEMIC RESEARCH IN BUSINESS AND SOCIAL SCIENCES Vol. 10, No. 6, June, 2020, E-ISSN: 2222-6990 @ 2020 HRMARS

surroundings. Past researches on the subject were mostly conducted in the middle east where the views on native English speakers have not exactly been favourable despite the efforts to include the language in education (Abouelhassan \& Meyer, 2016). By comparison, English is considered a second language in Malaysia and is highly regarded as an essential tool in modern society to gain knowledge and economic status. Therefore, it is still imperative to examine the religious beliefs and values of the community when teaching English.

\section{Conclusion and Recommendation for Future Studies}

To conclude this paper, it was found that undergraduates enrolled in an Islamic-oriented education HR programme have high acceptance towards English language and strongly disagreed that the language negatively influenced their identity and values as Muslims. The findings differ from past studies which suggest the influence of geographical location, politics and time on the level of acceptance towards learning English.

Future research should focus on students' perception on how English language influences their Islamic identity and value and whether it affects their achievement and acquisition of the language. Perhaps a comparative study between students enrolled in Islamic-oriented and the common HR programmes can shed more light on the impact that different religious perception has on English language classroom.

\section{References}

Abouelhassan, R. S. M., \& Meyer, L. M. (2016). Economy, modernity, Islam, and English in Egypt. World Englishes, 35(1), 147-159. https://doi.org/10.1111/weng.12171

Ahmad, A., \& Rabai, A. (2014). Teaching English in the Arab World : A Future in Turmoil. Education, 4(5), 126-133. https://doi.org/10.5923/j.edu.20140405.04

Ahmed, S. (2015). Attitudes towards English Language Learning among EFL Learners at UMSKAL. Journal of Education and Practice, 6(18), 6-17.

Alazzany, M. A. O. A. (2008). A Critical Discourse Analysis of the Representation of Islam and Muslims Following the 9/11 Events as Reported in The New York Times (Unpublished doctoral dissertation). Universiti Putra Malaysia (UPM), Malaysia.

Asmah, H. O. (1992). The Linguistic Scenery in Malaysia. Dewan Bahasa dan Pustaka.

Atay, D., \& Ece, A. (2009). Multiple Identities as Reflected in English-Language Education: The Turkish Perspective. Journal of Language, Identity \& Education, 8(1), 21-34. https://doi.org/10.1080/15348450802619961

Bidin, S., Jusoff, K., Aziz, N. A., Salleh, M. M., \& Tajudin, T. (2009). Motivation and Attitude in Learning English among UiTM Students in the Northern Region of Malaysia. English Language Teaching, 2(2), 16-20. https://doi.org/10.5539/elt.v2n2p16

Brown, H. D., \& Lee, Heekyeong. (2015). Teaching by Principles: An Interactive Approach to Language Pedagogy. Pearson Education.

Dan, W. C., Haroon, H. A., \& Naysmith, J. (1996). English and Islam in Malaysia: Resolving the tension? World Englishes, 15(2), 225-234. https://doi.org/10.1111/j.1467-

971X.1996.tb00108.x

Hadi, A. (2016). English, Islam, and Secular values in Pre-service English Teacher Education : Exploring the Curricular Balance. Proceedings of International Conference on Teacher Training and Education 2015. (pp. 254-263). 
INTERNATIONAL JOURNAL OF ACADEMIC RESEARCH IN BUSINESS AND SOCIAL SCIENCES Vol. 10, No. 6, June, 2020, E-ISSN: 2222-6990 @ 2020 HRMARS

Hyde, M. (1994). The Teaching of English in Morocco: The Place of Culture. ELT Journal, 48 (5), 295305.

Idris, N. A., Hasim, N. A., Jailani, A. I., Izhar, N. I., \& Fisoh, F. M. (2019). Achievement in English Language Courses and Students' exposure to The Language outside the Classroom. Jurnal Kesidang, 4(1), 11-22.

Jahedi, M., Abdullah, F. S., \& Jayakaran Mukundan. (2014). Review of Studies on Media Portrayal of Islam, Muslims and Iran. International Journal of Education and Research, 2(12), 297-308.

Jaspal, R., \& Coyle, A. (2010). "Arabic is the language of the Muslims-that's how it was supposed to be": Exploring language and religious identity through reflective accounts from young British-born South Asians. Mental Health, Religion and Culture, 13(1), 17-36. https://doi.org/10.1080/13674670903127205

Kim, L. S. (2003). Multiple Identities in a Multicultural World: A Malaysian Perspective. Journal of Language, Identity \& Education, 2(3), 159. https://doi.org/10.1207/S15327701JLIE0203

Mohd-Asraf, R. (2005). English and Islam: A Clash of Civilizations? Journal of Language, Identity \& Education, 4(2), 103-118. https://doi.org/10.1207/s15327701jlie0402_3

Ozog, C. (1989). English for Islamic purposes: A plea for cross-cultural understanding. Language teaching and learning styles within and across culture, 398-403.

Pennycook, A. (1994). The Cultural Politics of English as an International Language. Pearson Education Limited.

Rahman, T. (2009). The Muslim Response to English in South Asia: With Special Reference to Inequality, Intolerance, and Militancy in Pakistan. Journal of Language, Identity \& Education, 4(2), 119-135. https://doi.org/http://dx.doi.org/10.1207/s15327701jlie0402_4

Roscoe, A., \& Al-Mahrooqi, R. (2012). Literacy, Literature and Identity: Multiple Perspectives. Cambridge Scholars Publishing.

The importance of the english language in the workplace. (2009), Jobstreet. Retrieved from https://www.jobstreet.com.my/announcement/2009/d/survey.htm

Umam, C. (2014). Maintaining Islamic Values in English Language Teaching in Indonesian Pesantrens. Didaktika Religia, 2(1), 227-242.

Zare-ee, A., \& Hejazi, S. Y. (2017). University Teachers' Views on English as the Medium of Instruction in an Iranian Higher Education Institution Abbas. Arab World English Journal (AWEJ), 8(4), 467-485. https://doi.org/10.1017/CBO9781107415324.004 